\title{
STRATEGI PEMBANGUNAN BERBASIS MASYARAKAT DI KECAMATAN PERBATASAN NEGARA DI PROVINSI RIAU
}

\section{COMMUNITY DEVELOPMENT STRATEGY BASED IN BORDER STATES DISTRICT IN RIAU PROVINCE}

\author{
Gevisioner, Rindukasih Bangun, Karyanti \\ Badan Penelitian dan Pengembangan Provinsi Riau \\ Jalan Diponegoro No. 24 A Pekanbaru \\ e-mail: irgevisioner@gmail.com
}

Dikirim: 28 Februari 2013; direvisi: 12 Maret 2013; disetujui: 18 Maret 2013

\begin{abstract}
Abstrak
Wilayah perbatasan memerlukan sebuah mekanisme pengelolaan yang terintegrasi dan berkesinambungan. Penelitian ini bertujuan merumuskan strategi dan model pembangunan yang sesuai dengan kondisi wilayah pada Kecamatan Perbatasan Negara di Provinsi Riau. Lokasi penelitian ditentukan secara purposive di Kecamatan Rangsang Barat Kabupaten Kepulauan Meranti Provinsi Riau. Analisis data yang digunakan deskriptif dan kuantitatif. Hasil penelitian menunjukkan bahwa : pembangunan pada kecamatan perbatasan yang memiliki wilayah pesisir seharusnya dilakukan dengan melalui suatu pendekatan pembangunan yang menjamin terpeliharanya keseimbangan ekologi dan pertumbuhan ekonomi, yang dilakukan secara berkelanjutan dan terpadu, dengan meletakkan masyarakat sebagai basis pembangunan.

Kata kunci : Pembangunan, perbatasan, berbasis masyarakat, berkelanjutan
\end{abstract}

\begin{abstract}
The boarder area need a integrity and continually management mechanism. The purposes of this research to formulate the strategy and the model of development fringe which suitable with the area condition in the district of fringe country in Riau province. This research is done in the district of Rangsang Barat, Meranti regency of Riau province. The method of data analyzing that is used descriptive and quantitative. The result of research has shown the development of beach and ocean area should be done toward a development approach that keep the ecology balance and economic growing oprimally and sustainable with put the society as based development and doing it integraty.
\end{abstract}

Keyword : development, boarder area, society based, sustainable.

\section{PENDAHULUAN}

Kawasan perbatasan merupakan bagian dari wilayah negara yang terletak pada sisi dalam sepanjang batas wilayah dengan negara lain, dalam hal batas wilayah negara di darat, kawasan perbatasan berada di kecamatan (UU. No.43 tahun 2008). Pembangunan wilayah perbatasan pada hakekatnya merupakan bagian integral dari pembangunan nasional. Berdasarkan UndangUndang Republik Indonesia Nomor 26 Tahun 2007 tentang Penataan Ruang dan Peraturan Pemerintah Republik Indonesia Nomor 26 Tahun 2008 tentang Rencana Tata Ruang Wilayah Nasional, kawasan perbatasan digolongkan pada kawasan strategis, yang penataan ruangnya diprioritaskan dalam pelaksanaan pembangunan. Dalam era reformasi dan dengan kondisi kritis yang masih berkepenjangan, penanganan masalah perbatasan belum dapat dilakukan secara optimal (Sobar Sutisna,S, dkk, 2010).

Daerah perbatasan (border areas) memiliki keunikan tersendiri, baik ditinjau dari aspek geografis, sosial, dan cultural. Oleh karena itu, pengelolaan wilayah perbatasan memerlukan kebijakan yang menyeluruh (holistic), mengingat pegembangan wilayah perbatasan pada dasarnya bertujuan untuk menciptakan dan meningkatkan kegiatan-kegiatan ekonomi dan perdagangan antara kedua negara yang akan memberikan dampak bagi peningkatan kesejahteraan masyarakat setempat dan peningkatan pendapatan negara melalui kegiatan ekspor dan impor ( Patriadi,HB, 2010).

Kawasan perbatasan darat di Indonesia tersebar di 4 provinsi, 16 kabupaten dan 66 kecamatan. Sedangkan kecamatan perbatasan dikawasan laut meliputi 104 kecamatan yang tersebar di 20 provinsi dan 50 Kabupaten. RPJM Nasional periode 2010 - 2014 telah menetapkan prioritas pengembangan wilayah kabupaten/kota dikawasan perbatasan, dimana terdapat 38 kabupaten yang diprioritaskan pengelolaannya (Bappenas BNPP, 2010).

Pengelolaan kawasan perbatasan masih menghadapi permasalahan yang kompleks, baik dari sisi delimitasi dan demarkasi batas, pertahanan dan keamanan, maupun pembangunan kawasan. Dari sisi perencanaan, salah satu permasalahan 
pengelolaan kawasan perbatasan hingga saat ini belum tersedia rencana pembangunan yang beroritentasi kepada upaya pembangunan kawasan perbatasan terintegrasi dan terperinci (BappenasBNPP, 2010). Hingga saat ini kondisi perekonomian sebagian besar wilayah di kawasan perbatasan relatif masih tertinggal jika dibandingkan dengan pembangunan di wilayah lain. Di beberapa kawasan terjadi kesenjangan pembangunan kawasan perbatasan dengan negara tetangga. Kondisi ini pada umumnya disebabkan oleh masih terbatasnya ketersediaan sarana dan prasarana sosial ekonomi seperti sarana dan prasarana perhubungan, telekomunikasi, permukiman serta rendahnya kualitas sumberdaya manusia (Hadi, S, 2009).

Kabupaten Kepulauan Meranti termasuk satu dari lima Kawasan Prioritas Perbatasan Laut RISingapura/Malaysia/ Vietnam yang terdapat di Provinsi Riau, selain Kota Dumai, Kabupaten Bengkalis, Rokan Hilir dan Indragiri Hilir (Bappenas- BNPP, 2010). Bila ditinjau dari geografis kabupaten Kepulauan Meranti, merupakan kabupaten satu-satunya yang merupakan Kepulauan di provinsi Riau, memiliki empat gugus pulau besar dan 12 pulau kecil. Kondisi geografis yang yang berada di jalur pelayaran dan perdagangan international Selat Malaka dan berbatasan dengan dua Negara tetangga yakni Malaysia dan Singapura memberikan peluang dan ancaman dalam pembangunan di kabupaten Kepulauan Meranti.

Kabupaten Kepulauan Meranti memiliki potensi sumberdaya alam yang besar dan beragam. Selain memiliki potensi pertambangan minyak dan gas bumi, perairan, wilayah pesisir dan laut, juga memiliki lahan yang dapat dimanfaatkan sebagai sumber kehidupan bagi penduduk. Kawasan hutan mangrove (bakau) di kabupaten Kepulauan Meranti sudah banyak yang mengalami kerusakan. Tingkat pendidikan dan kesejahteraan penduduk di kabupaten Kepulauan Meranti relatif rendah, hal ini dapat dilihat masih tingginya persentase rumah tangga miskin di Kepulauan Meranti yang mencapai 34,85 persen. Pada beberapa kecamatan dengan persentase rumah tangga miskin mencapai 40 persen lebih, terutama pada kecamatan yang berbatasan langsung dengan Negara tetangga seperti kecamatan Rangsang Barat, sebagian besar penduduk miskin berada di pedesaan dan bekerja pada sektor pertanian (Bappeda Kepulauan Meranti, 2011).

Kondisi tersebut di atas menggambarkan bahwa pembangunan selama ini belum dapat meningkatkan kesejahteraan masyarakat secara signifikan karena belum sesuai dengan potensi sumber daya yang ada. Model pemberdayaan masyarakat yang selama ini digeneralisasi secara nasional atau berlaku untuk semua daerah, dengan asumsi bahwa kebutuhan masyarakat sama untuk seluruh daerah atau sama dengan kebutuhan penyusun kebijakan, menjadi penyebab utama pembangunan tidak dapat dimanfaatkan oleh masyarakat (penghamburan sumberdaya). Oleh karena itu, model pemberdayaan yang disusun secara nasional patut direevaluasi dan disesuaikan dengan kondisi masyarakat dan wilayah masing-masing. Seperti yang dikemukan oleh Sobar, dkk (2010) bahwa setiap kawasan perbatasan memiliki karakteristik yang berbeda-beda oleh karena itu pengelolaan pembangunan ditiap-tiap kawasan tersebut tidak dapat disamaratakan. Oleh karena itu, sudah sewajarnya bila wilayah perbatasan memerlukan sebuah mekanisme pengelolaan yang terintegrasi dan berkesinambungan, karena diruang perbatasan tersebut akan selalu terjadi pergesekan atau interaksi dengan Negara tetangga, baik positif maupun negative. $\mathrm{P}$ enanganan pembangunan wilayah pada setiap kawasan, mempunyai kondisi dan karakteristik berbeda-beda, sehingga focus pembangunannya akan berbeda-beda pula (Adisasmita, 2006).

1. Kabupaten Kepulauan Meranti yang merupakan wilayah kawasan gugus kepulauan dengan infrastruktur yang sangat terbatas dan persentase penduduk miskin yang tinggi. Kondisi ini menggambarkan bahwa strategi atau model pembangunan selama ini belum dapat meningkatkan kesejahteraan masyarakat. Peningkatan pemberdayaan dan partisipasi masyarakat dan penguatan kelembagaan masyarakat dalam pemanfaatan pengelolaan dan pengembangan sumberdaya yang dimiliki merupakan langkah-langkah strategis dalam pembangunan daerah perbatasan. Sehingga rumusan masalah dalam penelitian ini adalah: Bagaimana potensi sumberdaya pembangunan mencakup potensi fisik lingkungan, sosial dan ekonomi pada Kecamatan Perbatasan Negara di Provinsi Riau?

2. Apakah sektor dan komoditi potensial yang dapat meningkatkan kesejahteraan masyarakat pada Kecamatan Perbatasan Negara di Provinsi Riau?

3. Bagaimana strategi dan model pembangunan pada Kecamatan Perbatasan Negara di Provinsi Riau?

Terkait dengan rumusan permasalahan dimaksud, maka tujuan penelitian ini adalah :

1. Menganalisis potensi sumberdaya pembangunan meliputi fisik lingkungan, sosial dan ekonomi pada Kecamatan Perbatasan Negara di Provinsi Riau,

2. Menganalisis sektor dan komoditi apa saja yang potensial untuk meningkatan kesejahteraan masyarakat pada Kecamatan Perbatasan Negara di Provinsi Riau,

3. Merumuskan strategi dan model pembangunan yang sesuai dengan kondisi wilayah pada Kecamatan Perbatasan Negara di Provinsi Riau. 


\section{METODE PENELITIAN}

Ruang Lingkup, Tempat dan Waktu Penelitian

Mengingat begitu luasnya ruang lingkup pengelolaan perbatasan, maka ruang lingkup penelitian ini dibatasi pada mengetahui dan menganalisa kondisi fisik lingkungan, sosial dan ekonomi serta merumuskan strategi dan model pembangunan pada daerah perbatasan Negara di Provinsi Riau.

Penelitian dilakukan di Kecamatan Rangsang Barat Kabupaten Kepulauan Meranti Provinsi Riau, selama 8 (delapan) bulan dari bulan April 2011 sampai dengan November 2011. Pemilihan lokasi penelitian dilakukan dengan menggunakan pertimbangan (purposive), yakni kecamatan yang terletak paling luar yang berbatasan langsung dengan negara Malaysia, persentase rumah tangga miskin yang relatif tinggi $(34,91 \%)$ dan jumlah desa tertinggal paling banyak di kabupaten Kepulauan Meranti (Bappeda Kabupaten Kepulauan Meranti, 2010).

\section{Pendekatan Penelitian}

Berdasarkan sifat tujuan penelitian, penelitian ini bersifat menjelajah (exploratory studies). Penelitian ini menggunakan strategi studi kasus dan bersifat multi metode, dengan menggunakan pendekatan kualitatif. Alasan menggunakan penelitian kualitatif adalah karena penelitian ini membahas aspek perilaku dan dinamika kelompok yang sangat kompleks.

\section{Jenis Data dan Teknik Pengumpulan Data}

Sebagaimana ciri-ciri khusus yang dimiliki dalam metode studi kasus, maka teknik pengumpulan data dalam penelitan ini tidak tunggal, namun gabungan dari beberapa teknik pengumpulan data, yaitu : Rapid Rural Apraisal (RRA)/ Pengenalan pedesaan dalam waktu singkat, FGD (Focus Group Discussion), dan telaahan dokumen. Jenis data yang dikumpulkan dan digunakan dalam penelitian ini adalah data primer dan data sekunder. Data primer yang dikumpulkan yaitu data karakteristik masyarakat diperbatasan yang meliputi umur, mata pencaharian, pendapatan, tingkat pendidikan, aktivitas lintas batas, kendala atau hambatan dalam pelaksanaan kegiatan pembangunan (kekuatan, kelemahan, peluang dan tantangan). Data sekunder yang dikumpulkan meliputi kondisi fisik lingkungan (topografi, hidrologi, tanah), potensi dan pemanfaatan sumberdaya lahan (produksi, luas areal panen, produktivitas komoditi), Produk Domestik Regional Bruto/ PDRB. Dikumpulkan juga data sekunder mengenai sosial dan ekonomi masyarakat seperti jumlah penduduk, struktur penduduk, fasilitas pendidikan, fasilitas kesehatan, fasilitas komunikasi, serta sarana dan prasarana perekonomian, program pembangunan yang telah dilaksanakan. Data sekunder diperoleh dari instansi terkait seperti Bappeda, BPS, Kantor Camat, dan lain-lain.

\section{Metode Penentuan Responden}

Pemilihan lokasi responden pada penelitian ini dilakukan berdasarkan pertimbangan (purposive sampling) yakni desa yang memiliki penduduk terbanyak pada masing-masing letak desa pada masing-masing pesisir. Desa yang terpilih adalah Desa Kedapu Rapat (Desa di Pesisir Utara), Desa Bokor (Desa Pesisir Selatan) dan Desa Bantar (terletak diantara Pesisir Utara dan Selatan). Jumlah responden/ sample diperoleh dengan menggunakan rumus (Cochran, 2001):

$$
n=\frac{\frac{t^{2} P Q}{d^{2}}}{1+\frac{\left[\frac{t^{2} P Q}{d^{2}}-1\right]}{N}}
$$

\section{Keterangan:}

$$
\begin{array}{ll}
\mathrm{n} & =\text { jumlah sampel } \\
\mathrm{P} & =\text { probalitas keyakinan } \\
\mathrm{N} & =\text { jumlah populasi } \\
\mathrm{Q} & =1-\text { probalitas } \\
\mathrm{t} & =\mathrm{t} \text { table } \\
\mathrm{d} & =\text { standar error }
\end{array}
$$

Pada penelitian ini menggunakan tingkat probalitas keyakinan terhadap data sebesar $95 \%$, maka diperoleh nilai tabel sebesar 1,96 dan standar error sebesar 0,05.. Dengan menggunakan perhitungan rumus perhitungan diatas diperoleh jumlah sampel sebanyak 75 rumah tangga, yaitu 25 rumah tangga per desa. Responden yang diamati adalah kepala rumah tangga. Pemilihan responden dari setiap desa dilakukan secara acak. Pemilihan responden sebagai informan kunci dalam wawancara mendalam di tentukan berdasarkan pertimbangan penguasaan terhadap kondisi lokasi penelitian. Jumlah informan kunci sebanyak 5 (lima) orang yang berasal dari berbagai stakeholder.

\section{Analisis Data}

Metode analisis data yang digunakan dalam dalam penelitian ini antara lain metode deskriptif dan metode kuantitatif. Metode deskriptif digunakan untuk mengetahui kondisi daerah perbatasan kecamatan Rangsang Barat dan tingkat perkembangan pembangunannya, meliputi:tabulasi, peringkasan, dan penyajian dalam bentuk grafik atau gambar-gambar serta perhitungan ukuran deskripsinya, kemudian dilakukan analisa perbandingan.

Metode kuantitatif antara lain berupa, analisis potensi sumberdaya wilayah, analisis penyebaran fasilitas pelayanan sosial dan ekonomi wilayah dengan metode skalogram, analisis potensi sektor / 
komoditi dengan metode Location Quentient (LQ), analisis GINI untuk memperoleh distribusi pendapatan, analisis SWOT untuk merumuskan strategi pembangunan berbasis masyarakat.

\section{HASIL DAN PEMBAHASAN}

\section{Kondisi Fisik Lingkungan, Sosial dan Ekonomi}

Seluruh Desa di kecamatan Rangsang Barat merupakan Desa Pesisir, karena berbatasan langsung dengan garis pantai. Kondisi wilayah pesisir kecamatan Rangsang Barat secara umum sama dengan kondisi pesisir wilayah pantai timur Pulau Sumatera. Topografi wilayah kecamatan Rangsang Barat merupakan topografi datar, sebagian besar wilayah berada pada ketinggian kurang dari $50 \mathrm{mdpl}$, yang merupakan daerah pesisir. Iklim wilayah adalah tropis basah, tanpa bulan kering, dengan ratarata curah hujan $2500-3000 \mathrm{~mm}$, tipe Equatorial. Batuan induk yang mengalasi Rangsang Barat terdiri dari batuan aluvial dan bahan organik. Jenis tanah relatif homogen dengan kesuburan rendah - sedang. (Bappeda Kab. Kepulauan Meranti, 2011).

Ekosistem wilayah pesisir dan laut di kecamatan Rangsang Barat adalah ekosistem lahan rawa gambut dan kawasan mangrove. Pada umumnya lahan rawa gambut di dominasi oleh hutan rawa dan sagu. Sedangkan kawasan mangrove didominasi oleh hutan bakau, api-api dan nipah. Pada umumnya, kawasan hutan mangrove (bakau) di kecamatan Rangsang Barat sudah banyak yang mengalami kerusakan, karena dimanfaatkan oleh masyarakat.
$(33.33 \%)$ termasuk kedalam wilayah miskin. Desadesa yang masuk katergori miskin potensi sumberdaya adalah Segomeng, Lemang, Kayu Ara, Sendaur dan Bina Maju.

\section{Kondisi Sosial dan Ekonomi}

Tingkat pendidikan kepala keluarga di kecamatan perbatasan masih tergolong rendah. Hal ini dapat dari tingkat pendidikan kepala keluarga sebagian besar berpendidikan tidak tamat Sekolah Dasar (30,19 \%) dan Tamat Sekolah Dasar (26,42 $\%$ ). Walaupun didominasi sebagian besar berpendidikan Sekolah Dasar (SD), tingkat kesadaran masyarakat untuk bersekolah mencapai pendidikan yang lebih tinggi relative besar, hal ini dapat dilihat hampir 94.7 persen rumah tangga tidak mempunyai anak yang tidak bersekolah yang berada pada usia sekolah. Tingkat pendidikan masyarakat yang tergolong rendah dapat menyebabkan pola berpikir dan bertindak masyarakat dalam pembangunan sangat terbatas. Rendahnya pendidikan masyarakat, salah satunya disebabkan karena terbatasnya fasilitas pendidikan yang ada.

Fasilitas pendidikan yang terdapat di Kecamatan Rangsang Barat masih sangat terbatas. Pada tahun 2010 yakni 12 Taman Kanak-Kanak, 25 Sekolah Dasar, 5 Sekolah Lanjutan Tingkat Pertama, dan 3 Sekolah Menengah Umum. Sedangkan untuk Madrasah, memiliki 4 Madrasah Ibtidaiyah, 6 Madrasah Tsanawiyah, 2 Madrasah Aliyah dan 28 Madrasah Diniyah Awaliyah serta 1 Pondok Pesantren. Sementara untuk sekolah kejuruan (SMK) sampai saat ini belum ada. Penyebaran fasilitas

Tabel 1. Jenis Fasilitas Pelayaran Berdasarkan Derajat Penyebarannya di Kecamatan Rangsang Barat Tahun 2010

\begin{tabular}{ll}
\hline \multicolumn{1}{c}{$\begin{array}{c}\text { Derajat } \\
\text { Penyebaran }\end{array}$} & \multicolumn{1}{c}{ JENIS FASILITAS } \\
\hline Tinggi $(\geq 70 \%)$ & $\begin{array}{l}\text { TK/RA dan TPA, Sekolah Dasar, MDA, Toko/Kedai, Industri kecil, } \\
\text { Mesjid, Musholla }\end{array}$ \\
Sedang (35-70\%) & Koperasi, Pelabuhan Rakyat \\
Rendah $(\leq 35 \%)$ & $\begin{array}{l}\text { SLTP, SLTA, Pasar. Madrasah, Pesantren, Klinik KB, Puskesmas, } \\
\text { Restoran/Rumah Makan, BPR, Pegadaian, Gereja, Pura/Vihara, Hotel/ } \\
\text { Penginapan }\end{array}$ \\
\hline Sumber : Data Olahan $(2011)$
\end{tabular}

Berdasarkan hasil analisis hirarki potensi sumberdaya wilayah yang meliputi tanaman pangan, perkebunan, perikanan, peternakan, perdagangan, perindustrian, parawisata dan kependukuan pada setiap desa diperoleh bahwa pada tahun 2010, penyebaran sumberdaya kurang merata sehingga tingkat ketimpangan antar desa menjadi tinggi. Terdapat 6 desa $(40,00 \%)$ yang tergolong kedalam wilayah dengan potensi sumberdaya kaya, 4 desa $(26,67 \%)$ tergolong wilayah sedang dan 5 desa pendidikan, kesehatan, ekonomi, perhubungan dan komunikasi seperti jalan, listrik dan air bersih sangat rendah di kecamatan Rangsang Barat (Tabel 1)

Fasilitas pelayanan di kecamatan Rangsang Barat sebagian besar memiliki derajat penyebaran rendah ( $\leq 35 \%)$. Fasilitas pelayanan yang keberadaannya hanya terbatas pada beberapa desa ini merupakan fasilitas yang mempunyai jangkauan pelayanan yang luas seperti SLTP, SLTA, Sarana 
Kesehata (Puskesmas, Pustu, Klinik KB), Pasar dan lain-lain.

Mata pencaharian penduduk terutama kepala keluarga di Kecamatan Rangsang Barat menunjukkan bahwa kepala keluarga mempunyai pekerjaan utama pada sector pertanian secara umum seperti sebagai nelayan ( $32.08 \%)$, petani $(35,95 \%)$, buruh tani dan angkut $(11,32 \%)$, pedagang $(5,66 \%)$. Sebanyak 41,51 persen kepala keluarga mempunyai pekerjaan tambahan. Pekerjaan tambahan di bidang pertanian mencapai $31,82 \%$, buruh 22,73 persen, pedagang 18.18 persen.

Kepala keluarga di kecamatan Rangsang Barat mempunyai rata-rata pendapatan $\mathrm{Rp}$. 1.501 .900 /bulan. Pendapatan tersebut, 73,40 persen, berasal dari pekerjaan utama, sedangkan sisanya dari pekerjaan tambahan. Berdasarkan pengelompokkan pendapatan, 63.33 persen rumah tangga mempunyai pendapatan sebesar Rp.1.000.000,- s/d Rp. 2.000.000, per bulan, dan kurang dari Rp.1.000.000,terdapat sebanyak 17,33 persen. Pendapatan tersebut digunakan 56,76 persen untuk biaya konsumsi pangan, 15.79 persen untuk biaya transportasi, dan selebihnya untuk biaya pendidikan, kesehatan dan lain-lain.

Distribusi pendapatan digunakan untuk melihat ketimpangan pendapatan rumah tangga. Hasil perhitungan Gini Ratio diperoleh bahwa pada $40 \%$ pendapatan terendah menerima $24.29 \%$ dari total pendapatan kepala keluarga sampel, $40 \%$ pendapatan menengah memperoleh 40.04 dari total pendapatan kepala keluarga petani, sedangkan untuk $20 \%$ pendapatan teratas memperoleh 35,66\% dari total pendapatan. Angka Gini Ratio sebesar 0.22, yang menunjukkan bahwa tingkat kesenjangan atau ketimpangan pembagian pendapatan rendah (Tabel 2).

\section{Tabel 2. Distribusi Pendapatan Yang Diterima Keluarga di Kec. Rangsang Barat}

\begin{tabular}{llcc}
\hline No & Golongan & $\begin{array}{c}\text { Tingkat } \\
\text { Pendapatan } \\
(\mathrm{Rp})\end{array}$ & $\begin{array}{c}\text { Pendapatan } \\
\text { Dalam Kelas } \\
(\%)\end{array}$ \\
\hline 1. & $\begin{array}{l}40 \% \\
\text { terbawah }\end{array}$ & 25.460 .000 & 24.29 \\
2. & $\begin{array}{l}40 \% \\
\text { menengah }\end{array}$ & 43.662 .000 & 40.04 \\
$3 . \quad \begin{array}{l}20 \% \\
\text { teratas }\end{array}$ & 38.850 .000 & 35.66 \\
\hline
\end{tabular}

Sumber :Data Olahan (2011)

\section{Tingkat Kesejahteraan}

Jumlah desa tertinggal di kecamatan Rangsang Barat pada tahun 2010 berjumlah 11 desa atau 73.3 persen dari total desa yang ada. Tingkat kesejahteraan penduduk di kecamatan Rangsang Barat masih sangat rendah, karena masih terdapat 34.91 persen rumah tangga miskin (Bappeda Kab.Meranti. 2011). Disamping masih terdapatnya 4.4 persen balita yang berada pada kondisi status gizi buruk, dan 11,7 persen yang mengalami gizi kurang pada tahun 2010 (Dinas Kesehatan Kabupaten Kepulauan Meranti, 2010). Tingkat kesejahteraan masyarakat di kecamatan perbatasan ini sangat dipengaruhi oleh ketersediaan fasilitas ekonomi di daerah tersebut.

Dari analisis hirarki fasilitas sosial ekonomi (pendidikan, kesehatan, ekonomi, peribadatan, parawisata, perhubungan, komunikasi, kepadatan penduduk dan lokasi desa) dengan skalogram , menunjukkan bahwa terdapat 5 desa (33.33\%) yang terletak diperbatasan negara yang termasuk wilayah tertinggal, 6 desa $(40.00 \%)$ yang termasuk berkembang, sedangkan 4 desa $(26,67 \%)$ yang termasuk wilayah maju, yakni desa Bantar, Bokor, Kedabu Rapat dan Tanah Merah. Dari hasil analisis skalogram diketahui bahwa desa Bantar, Bokor dan Kedabu Rapat menempati hirarki hirarki tertinggi. Kondisi ini menggambarkan tingkat ketimpangan antar desa di kecamatan Rangsang Barat. Oleh karena itu, dari analisis skalogram tersebut dapat disimpulkan bahwa ternyata terdapat 3 desa yang dapat menjadi pusat pelayanan atau pusat pengembangan wilayah utama adalah desa Bantar, Bokor dan Kedabu Rapat.

Desa-desa yang berada di daerah pantai/pesisir pada umumnya memiliki unit sarana dan prasarana paling sedikit, terutama yang terkait dengan infrastruktur dasar. Masalah infrastruktur yang terutama adalah jalan, listrik, dan air bersih. Jalan-jalan didaerah perbatasan umumnya adalah sedang hingga rusak. Jalan jalan yang menghubungi desa ke desa apalagi jalan usaha tani dalam kondisi rusak, begitu juga keterbatasan jembatan yang ada. Persentase kondisi jalan yang baik di kecamatan Rangsang Barat relatif lebih sedikit dibanding kondisi jalan yang rusak, disamping jenis jalan tanah yang masih lebih banyak dibanding jenis jalan aspal dan kerikel. Kondisi ini membuat perkembangan ekonomi masyarakat di kecamatan perbatasan terkendala, mengingat untuk mengeluarkan hasil pertanian dari lahan usaha tani ke pemasaran menjadi lebih sulit dan mahal .

Ketertinggalan secara ekonomi juga dirasakan oleh masyarakat perbatasan di Kecamatan Rangsang Barat dipicu oleh minimnya infrastruktur dan aksesibilitas yang tidak memadai, seperti jaringan jalan dan angkutan perhubungan laut maupun darat masih sangat terbatas. Hubungan antar sebagian besar desa, baru dapat dilalui dengan kendaraan roda 2 dengan kondisi sebagian besar rusak (panjang jalan yang dapat dilalui kendaraan roda 4 hanya sepanjang $20 \mathrm{~km}$ ), prasarana dan sarana komunikasi seperti pemancar atau transmisi radio dan televisi serta sarana telepon relatif minim, ketersediaan sarana dasar sosial dan ekonomi seperti pusat kesehatan masyarakat, sekolah, dan pasar juga sangat terbatas. Terbatasnya sarana dan prasarana komunikasi, khususnya yang dapat menggambarkan perkembangan kemajuan pembangunan di Provinsi 
Riau dan Indonesia secara umum, mengakibatkan masyarakat lebih cenderung mendengar dan melihat program-program televise dari Negara tetangga. Kondisi keterbatasan tersebut akan semakin nyata dirasakan oleh masyarakat perbatasan ketika mereka membandingkan dengan kondisi pembangunan di negara tetangga Malaysia khususnya kota Batu Pahat.

\section{Aktivitas Lintas Batas}

Aktivitas lintas batas merupakan kegiatan yang biasa terdapat pada daerah yang terdapat pada perbatasan suatu Negara. Kepala keluarga yang melakukan perjalanan/kunjungan ke Negara tetangga (Malaysia) dalam setahun dengan frekuensi 1- 2 kali sebanyak 18,67 persen. Kegiatan lintas batas dilakukan dalam rangka mencari kerja $(57,14 \%)$ dan berdagang $(42,86 \%)$. Kegiatan mencari kerja dan berdagang pada umumnya dengan alasan pendapat di negara tetangga lebih besar. Aktivitas perdagangan yang dilakukan adalah menjual hasil pertanian seperti ikan, karet, kopi, pinang, arang kayu, sedangkan dari Negara tetangga yang dibawah adalah kebutuhan bahan makanan (sembako) seperti gula, tepung,susu, beras, dan makanan kecil lainnya dan kadang-kadang furniture dan semen.

Transportasi yang digunakan adalah kapal kayu mesin. Hampir 62.5 persen melakukan aktivitas perdagangan melalui perantara, dan 87,5 persen tidak melalui pintu entry point (Teluk Belitung dan Tanjung Samak), karena dianggap terlalu jauh oleh masyarakat serta nilai perdagangan yang diperbolehkan RM 600 masih relative rendah. Seperti aktivitas lintas batas yang dilakukan dari pelabuhan Kedabu Rapat, terdapat 4 kapal yang melakukan aktivitas rutin ke Negara tetangga setiap bulan, 1 kapal setiap minggunnya. Setiap kapal memuat 5 anak buah kapal. Aktivitas lintas batas yang dilakukan ini seakan-akan mendapat permakluman dari muspida setempat.

\section{Potensi Wilayah}

Analisis potensi wilayah terkait untuk menentukan sektor-sektor yang perlu dikembangkan agar perekonomian daerah tumbuh cepat. Hasil perhitungan LQ di kabupaten Kepulauan Meranti memberikan gambaran bahwa pada tahun 2009 terdapat dua sektor / lapangan usaha yang menjadi basis (LQ > 1) pembangunan yakni sector pertanian, perdagangan, hotel dan restoran. Sektor pertanian, sektor perdagangan, hotel dan restoran menjadi sektor basis di kabupaten Kepulauan Meranti sangatlah relevan dengan peran ketiga sektor tersebut dalam membentuk PDRB kabupaten Kepulauan Meranti yang begitu dominan. Mengingat potensi dan kondisi saat ini dimana wilayah kecamatan Rangsang Barat yang memiliki potensi lahan sawah yang lebih besar dibanding kecamatan lainnya, maka dapat dikatakan bahwa sektor pertanian secara umum, menjadi sektor basis untuk pengembangan pembangunan di kecamatan Rangsang Barat. Seperti yang dikemukakan oleh Tarigan, R (2005), bahwa nilai LQ pada tingkat yang lebih tinggi seperti Kabupaten/Kota, secara umum dapat menggambarkan nilai LQ pada tingkatan yang lebih rendah atau wilayah kecamatan pada kabupaten tersebut, bila dilihat dari potensi dan kondisi kecamatan. Sehingga berdasarkan klasifikasi sub sektor, kabupaten Kepulauan Meranti mempunyai beberapa sub sektor yang memiliki nilai LQ lebih dari satu. Pada tahun 2007 - 2008 terdapat 8 (delapan ) sub sektor basis. Sub sektor tersebut adalah sub sektor tanaman bahan makanan $(1,43)$, peternakan $(1,47)$, kehutanan $(1,83)$, dan perikanan ( $1,07)$ dari sektor pertanian; sub sektor industri tanpa migas $(1,10)$ dari sektor industri pengolahan; sub sektor perdagangan $(1,75)$ dari sektor perdagangan, hotel dan restoran; sub sektor pengangkutan laut $(2,10)$, jasa penunjang pengangkutan $(1,41)$ dari sektor pengangkutan dan komunikasi (Bangun, RK, dkk, 2009).

\section{Komoditi Basis/Potensial}

Penentuan komoditi basis masing-masing sub sektor diketahui metode Location Quetion (LQ). Komoditi basis bila nilai LQ komoditi tersebut lebih dari satu ( $\mathrm{LQ}>1$ ), yang mempunyai bahwa komoditi tersebut menjadi komoditas basis atau sumber pertumbuhan. Komoditas itu memiliki keungulan komparatif, dapat memenuhi kebutuhan wilayah tersebut dan memasok ke luar wilayah (Hendayana, 2003). Komoditi basis tanaman pangan dan hortikultura untuk wilayah kecamatan Rangsang Barat adalah padi (1.05), durian (2.88), pisang $(1,92)$, sawi $(1,14)$, kacang panjang (1.05). Komoditi basis tanaman perkebunan yaitu karet (1.67), kelapa (2.24), kopi (6.60) dan pinang (6.03). Komoditi basis perikanan yakni perikanan laut (1.0) sedangkan komoditi basis dari peternakan adalah kambing (5.37), sapi (1.42), ayam kampong (1.85) dan itik (1.25).

Sektor pertanian yang memiliki keunggulan di kecamatan Rangsang Barat, memiliki prospek yang lebih baik untuk dikembangkan dan diharapkan dapat mendorong sektor-sektor lain untuk berkembang. Percepatan pembangunan dengan sector pertanian dapat dilakukan melalui upayaupaya antara lain : (1) peningkatan keberdayaan masyarakat pedesaan, (2) pengembangan ekonomi lokal, (3) penyediaan infrastruktur sosial ekonomi dan lingkungan; (4) penguatan kapasitas kelembagaan pemerintahan, usaha ekonomi dan lembaga swadaya masyarakat setempat. Model pembangunan pertanian yang dapat dilakukan di kecamatan Rangsang Barat dapat berupa kawasan agropolitan. Pola pengembangan spasialnya berbentuk koridor yang membentang sepanjang perbatasan, dengan demikian diharapkan akan mendorong pengembangan ekonomi berbasis pertanian diwilayah hinterland. 


\section{Alternatif Strategi Pembangunan}

Hasil analisis lingkungan internal di kecamatan perbatasan (Kecamatan Rangsang Barat), diperoleh factor kekuatan adalah : (1) Tersedianya potensi sumberdaya alam, (2) Letak geofrafis yang
Tingginya permintaan pasar terhadap produk pertanian, Faktor-faktor ancaman yang harus diatas adalah: (1) Kesenjangan tingkat pendapatan penduduk dengan negara tetangga, (2) Masih terdapat beberapa kebijakan pemerintah pusat dan daerah tentang pengelolaan perbatasan yang tidak

\begin{tabular}{|c|c|c|}
\hline Faktor Eksternal & $\begin{array}{l}\text { Kekuatan (S) } \\
\text { 1. Tersedianya potensi } \\
\text { sumberdaya alam yang besar } \\
\text { 2. Letak geografis yang strategis } \\
\text { 3. Persamaan bahasa dan budaya } \\
\text { dengan Negara tetangga } \\
\text { 4. Besarnya keinginan masyarakat } \\
\text { untuk terlibat dalam } \\
\text { pembangunan }\end{array}$ & 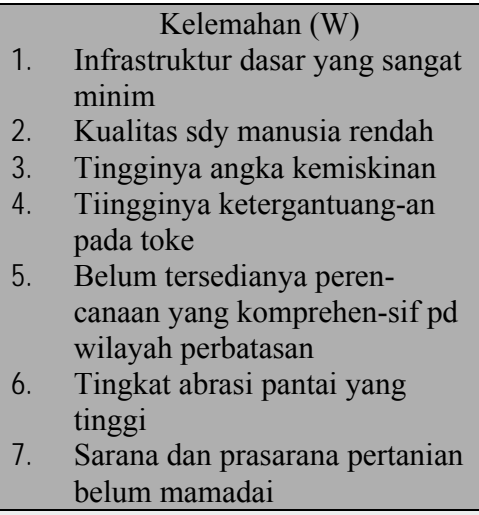 \\
\hline Peluang $(\mathrm{O})$ & Strategi S-O & Strategi $\mathrm{W}-\mathrm{O}$ \\
\hline $\begin{array}{ll}\text { 1. } & \text { Perkembangan Teknologi dan } \\
\text { Informasi } \\
\text { 2. } \\
\text { 3. } \\
\text { Beranganada Otonomi Daerah } \\
\text { 4. } \\
\text { perdagangan terpadat di dunia } \\
\text { Produk Pertanian }\end{array}$ & $\begin{array}{l}\text { 1. Memanfaat potensi sumberdaya } \\
\text { yang berkelanjutan dengan } \\
\text { mengoptimal-kan OTDA } \\
\text { 2. Optimalisasi keterlibatan masya- } \\
\text { rakat dalam pembangunan }\end{array}$ & $\begin{array}{l}\text { 1. Penyiapan infrastruktur dasar } \\
\text { (jalan/jembatan, listrik, air } \\
\text { bersih, pelabuhan) } \\
\text { 2. Peningkatan kualitas SDM } \\
\text { dengan lebih melibatkan peran } \\
\text { aktif masyarakat dan seluruh } \\
\text { stakeholders } \\
\text { Optimalisasi pengembang-an } \\
\text { sarana dan prasarana pertanian }\end{array}$ \\
\hline Ancaman (T) & Strategi S- T & Strategi $\mathrm{W}-\mathrm{T}$ \\
\hline $\begin{array}{ll}\text { 1. } & \text { Kesenjangan tingkat } \\
\text { pendapatan penduduk dengan } \\
\text { negara tetangga } \\
\text { 2. Kebijakan pemerintah pusat } \\
\text { dan daerah tentang } \\
\text { pengelolaan perbatasan yang } \\
\text { kurang saling mendukung } \\
\text { 3. Kerusakan Lingkungan } \\
\text { 4. Rawan kegiatan illegal } \\
\text { 5. Konflik batas } \\
\text { 6. Sasaran utama jika terjadi } \\
\text { perti-kaian / peperangan antar } \\
\text { bangsa. }\end{array}$ & $\begin{array}{l}\text { 1. Peningkatan dan pemanfaatan } \\
\text { SDA secara optimal dan } \\
\text { berkelanjutan untuk mengha- } \\
\text { dapi persaingan antar wilayah } \\
\text { dan eraglobalisasi } \\
\text { 2. } \\
\text { 7. Sinkronisasi perencanaan } \\
\text { pem-bangunan ran } \\
\text { memformula-sikan kebijakan } \\
\text { daerah perba-tasan dengan } \\
\text { mempertim-bangkan kondisi } \\
\text { potensi daerah ran dan } \\
\text { kelembagaan lokal }\end{array}$ & $\begin{array}{l}\text { 1. Pengembangan potensi } \\
\text { unggulan daerah yang } \\
\text { berwawasan lingkungan } \\
\text { 2. } \begin{array}{l}\text { Optimalisasi peningkatan } \\
\text { peranan lembaga pemerintah }\end{array}\end{array}$ \\
\hline
\end{tabular}

Sumber: Hasil Penelitian Tahun 2011.

strategis, (3) Persamaan bahasa dan budaya dengan Negara tetangga, 4) Besarnya keinginan masyarakat untuk terlibat dalam pembangunan. Faktor kelemahan adalah: (1) Infrastruktur dasar seperti jalan, pelabuhan, listrik dan air bersih masih minim, (2) Sarana dan prasarana perikanan dan pertanian belum mamadai, (3) Kualitas sumberdaya manusia yang masih relatif rendah, (4) Tingginya angka kemiskinan, (5) Tingginya ketergantungan pada toke, 6) Belum tersedianya perencanaan pembangunan yang komprehensif, (7) Tingkat abrasi pantai yang tinggi.

Sedangkan dari analisis lingkungan eksternal diperoleh peluang dan ancaman. Faktor-faktor peluang meliputi (1) Perkembangan Teknologi dan Informasi, (2) Dukungan Otonomi Daerah, (3) Berada pada jalur perdagangan terpadat di dunia, (4) saling mendukung, (3) Kerusakan lingkungan, (4) Rawan kegiatan ilegal, (5) Konflik batas, (6) Sasaran utama jika terjadi pertikaian / peperangan antar bangsa.

Hasil analisis Matriks SWOT (Tabel 3), diperoleh bahwa alternatif strategi pengelolaan sumberdaya pembangunan di kecamatan perbatasan negara khususnya kecamatan Rangsang Barat adalah: (a) Penyiapan infrastruktur dasar (jalan, pelabuhan, listrik, air bersih) dan rehabilitasi kawasan manggove untuk penyelamatan albrasi pantai, (b) Peningkatan kualitas SDM melalui jalur formal dan informal kejuruan, (c) Optimalisasi pengembangan sarana dan prasarana sumberdaya perikanan dan pertanian, (d) Sinkronisasi perencanaan pembangunan dalam memformulasikan kebijakan 
daerah perbatasan dengan mempertimbangkan kondisi potensi daerah dan kelembagaan lokal.

Alternatif strategi pembangunan tersebut diatas, dilakukan dengan lebih melibatkan peran aktif masyarakat dan seluruh stakeholders. Alternatif strategi-strategi tersebut diatas perlu diawali dengan penyusunan rencana detail tata ruang kawasan perbatasan di kabupaten Kepulauan Meranti, yang merupakan penjabaran dari rencana tata ruang wilayah kabupaten. Kemudian diikuti dengan penyusunan rencana aksi pengelolaan kawasan perbatasan dengan melibatkan secara aktif masyarakat yang tinggal di kawasan perbatasan melalui proses musyawarah dan konsultasi publik yang intensif dalam setiap tahapan proses pembangunan.

\section{Model Pembangunan Berbasis Masyarakat}

Pembangunan yang dilaksanakan di kecamatan perbatasan tidak terlepas dari Rencana Pembangunan Jangka Menengah Daerah (RPJMD) Provinsi dan Kabupaten . Dari analisis dari RPJMD Provinsi Riau 2009 - 2013, dan RPJMD Kabupaten Kepulauan Meranti, diperoleh bahwa Meskipun RPJMD telah mengeksplisitkan pembangunan daerah perbatasan, guidance untuk melakukan pembangunan secara khusus pada kecamatan perbatasan negara belum ada. Sehingga, daerah perbatasan masih dilihat dalam kacamata yang sama dengan daerah lain sehingga implementasi programnya disamakan dengan program umum yang berlaku bagi seluruh kecamatan. Selain itu instrument perencanaan pembangunan khusus untuk kecamatan perbatasan negara belum tersedia. Sedangkan menurut Malik Hemen (2009), mengemukakan bahwa pembangunan tanpa memperhatikan kharakteristik dan kebutuhan lokal akan banyak membuang sumberdaya secara sia-sia. Dari penyataan responden diperoleh bahwa hanya 44 persen responden yang menyatakan bahwa program/kegiatan pembangunan yang ada selama ini, memberikan manfaat bagi kesejahteraan masyarakat. Hal ini berarti bahwa strategi dan model pembangunan yang ada selama ini belum secara optimal dapat meningkatkan kesejahteraan di kecamatan Rangsang Barat. Hanya beberapa program pembangunan yang dirasakan memberikan manfaat meskipun masih relative kecil. Program peningkatan kapasitas ekonomi pedesaan (Usaha Ekonomi Desa Simpan Pinjam (UED-SP), PNPM Mandiri Pedesaan perlu diperluas sesuai dengan karakteristik wilayah di kecamatan perbatasan Negara, serta lebih melibatkan peran masyarakat baik dari aspek perencanaan, pelaksanaan hingga pengawasan terhadap program yang ada.

Memperhatikan karakteristik kondisi fisik lingkungan, potensi sumberdaya pembangunan yang ada di kecamatan Rangsang Barat, merupakan suatu system dengan kompleksitas yang sangat tinggi ditilik dari segi sumberdaya alam maupun sumberdaya manusia. Sumberdaya alam pesisir sangat beragam dan sangat khas dibandingkan karakteristik sumberdaya alam yang dijumpai pada ekosistem lainnya. Demikian pula dengan sumberdaya manusia yang mendiami wilayah ini memiliki karakteristik yang kompleks. Oleh karena itu pembangunan wilayah pesisir seharusnya dilakukan dengan melalui suatu pendekatan pembangunan yang menjamin terpeliharanya keseimbangan ekologi dan pertumbuhan ekonomi. Pemeliharaan lingkungan hidup yang lestari seperti rehabilitasi dan peliharaan kawasan hutan mangrove, suatu keharusan. Kedua tujuan (ekologi-ekonomi) tersebut akan tercapai melalui suatu kebijakan pembangunan yang optimal dan berkelanjutan yang meletakkan masyarakat sebagai basis pembangunan dan dilakukan secara terpadu.

Keterpaduan yang dibutuhkan meliputi tiga unsur, yaitu keterpaduan antar sektoral, keterpaduan antar disiplin ilmu dan keterpaduan antar berbagai ekosistem yang membentuk wilayah pesisir dan lautan. Sedangkan masyarakat sebagai basis pembangunan wilayah pesisir dan lautan mengandung pengertian bahwa masyarakat (penduduk lokal, LSM, Swasta, perguruan tinggi) menjadi pelaku utama dalam proses pembangunan sejak tahap perencanaan, penyusunan program, pelaksanaaan hingga evaluasi kegiatan pembangunan yang dilakukan.

Masyarakat menjadi kunci bagi keberhasilan pengelolaan wilayah pesisir dan lautan. Peran pemerintah lebih terkonsentrasi pada tataran koordinasi diantara berbagai stakeholder untuk menjamin terpeliharanya kejelasan wewenang keterpaduan antar dimensi dalam pembangunan di kecamatan perbatasan Negara (kecamatan Rangsang Barat). Pada akhirnya melalui strategi pembangunan wilayah pesisir terpadu berbasis masyarakat akan menghasilkan suatu pembagian tanggung jawab antara pemerintah pada semua tingkat dalam lingkup pemerintahan maupun sektoral dengan pengguna sumberdaya (stakeholder) dalam pengelolaan daerah perbatasan yang memilki karakteristik wilayah pesisir dan lautan. Dapat diartikan strategi pengelolaan terpadu berbasis masyarakat ini pada hakekatnya baik masyarakat maupun pemerintah sama-sama diberdayakan (Gambar 1).

\section{SIMPULAN}

Strategi dan model pembangunan yang digunakan selama ini di kecamatan Rangsang Barat belum dapat meningkatkan kesejahteraan masyarakat sesuai yang diharapkan, hal ini terlihat dari masih tingginya persentase jumlah penduduk miskin, terbatasnya sarana pendidikan (sekolah; guru), sarana kesehatan (dokter, akses obat, puskesmas) dan minimnya infrastruktur dasar (jalan, jembatan, listrik, air bersih, sarana teknologi komunikasi dan informasi), terbatasnya keberadaan lembaga 
perekonomian (pasar, koperasi, lembaga keuangan). Sektor pembangunan yang potensial untuk dikembangkan ke depan di kecamatan Rangsang Barat) meningkatan kesejahteraan masyarakat adalah adalah sektor pertanian, dengan komoditi basis antara lain: padi, karet, kopi, perikanan laut, kambing, dan itik. Alternatif strategi yang dapat ditempuh dalam pengelolaan sumberdaya pembangunan untuk mempercepat di kecamatan perbatasan negara khususnya kecamatan Rangsang Barat adalah : (a) Penyiapan infrastruktur dasar (jalan, pelabuhan, listrik, air bersih) dan rehabilitasi kawasan manggove untuk penyelamatan albrasi pantai , (b) Peningkatan kualitas SDM melalui jalur formal dan informal kejuruan, (c) Optimalisasi pengembangan sarana dan prasarana sumberdaya perikanan dan pertanian, (d) Sinkronisasi perencanaan pembangunan dalam memformulasikan kebijakan daerah perbatasan dengan mempertimbangkan kondisi potensi daerah dan kelembagaan lokal, Alternatif strategi pembangunan tersebut diatas, dilakukan dengan lebih melibatkan peran aktif masyarakat dan seluruh stakeholders.

Pembangunan pada kecamatan perbatasan yang memiliki wilayah pesisir dilakukan dengan pendekatan pembangunan yang menjamin terpeliharanya keseimbangan ekologi dan pertumbuhan ekonomi, yang dilakukan secara berkelanjutan dan terpadu, dengan meletakkan masyarakat sebagai basis pembangunan. Upaya untuk mewujudkan kawasan perbatasaan negara sebagai beranda terdepan dalam konsep pembangunan maka diperlukan penyiapan infrastruktur dasar (jalan, pelabuhan, listrik, air bersih ) dan rehabilitasi kawasan manggove untuk penyelamatan dari abrasi pantai, serta penyediaan kelembagaan perekonomian seperti pasar, koperasi dan lembaga keuangan yang dilakukan secara terpadu. Sedangkan untuk mendukung peningkatan ekonomi masyarakat perlu regulasi kebijakan perdagangan lintas batas yang ada seperti penambahan entry/ exit point lintas batas serta sarana/prasarana pendukung, peningkatan volume dan nilai perdagangan. Supaya upaya-upaya pembangunan di kecamatan perbatasan negara, lebih terarah diperlukan pembentukan lembaga koordinasi pembangunan yang bertugas mengelola wilayah perbatasan negara seperti Badan Daerah Pengelola Perbatasan di Provinsi Riau dan kabupaten sebagai implementasi UU No. 43 tahun 2008 tentang Wilayah Negara.

\section{DAFTAR PUSTAKA}

Adisasmita, Rahardjo. 2006. Pembangunan Kelautan dan Kewilayahan. Edisi Pertama. Graha Ilmu. Yogyakarta

Bappenas-BNPP. 2010. Draft Rencana Induk Pengelolaan Batas Wilayah Negara dan Kawasan Perbatasan. Decentralization Support
Facility (DSF) BAPPENAS - BNPP- PT.Pillar Pusaka Inti. Jakarta

Bappeda Kabupaten Kepulauan Meranti 2010. Kabupaten Kepulauan Meranti Dalam Angka 2010. Kerjasama Badan Pusat Statistik Kabupaten Kepulauan Meranti dan Bappeda Kabupaten Kepulauan Meranti. Selat Panjang

Bappeda Kabupaten Kepulauan Meranti. 2011. Profil Kabupaten Kepulauan Meranti. Badan Perencanaan Pembangunan Daerah Kabupaten Kepualauan Meranti. Selat Panjang.

Bappeda Kabupaten Kepulauan Meranti. 2010. Draft Rencana Pembangunan Jangka Menengah Daerah Kabupaten Kepulauan Meranti Tahun 2011 - 2015. Badan Perencanaan Pembangunan Daerah Kabupaten Kepualauan Meranti. Selat Panjang.

Bangun, RK, dkk, 2009. Analisis Potensi Ekonomi Dan Strategi Pembangunan Ekonomi Di Daerah Otonom Baru Kabupaten Kepulauan Meranti Provinsi Riau. Badan Penelitian dan Pengembangan Provinsi Riau. Pekanbaru

Cochran, W.G. 2001. Teknik Penarikan Sampel. Universitas Indonesia Press. Jakarta

Hadi, Suprayoga (2009): Program Pembangunan Kawasan Perbatasan

"Strategi Pengembangan Perbatasan Wilayah Kedaulatan NKRI". http: //buletinlitbang. dephan. go.id, diakses tanggal 11 Desember 2010

Hendayana, Rachmat. 2003. Aplikasi Metode Location Quotient (LQ) Dalam Penentuan Komoditas Unggulan Nasional. Informatika Pertanian, Volume 12. Jakarta

Malik Hemen. 2009. Pembangunan Berbasis Masyarakat Mungkinkah Dapat Menjawab Masalah Sosial. Lembaga Pengkajian Pembangunan Bengkulu. http://wecarebengkulu.wordpress.com/2009/06/2 $\underline{4}$, diakses tanggal 4 Desember 2010

Patriadi, H.B, 2010. Isu Perbatasan : Memudarnya 'Imagined State?, dalam Mengelola Perbatasan Indonesia Didunia Tanpa Batas, Isu, Permasalahan dan Pilihan Kebijakan. Graha Ilmu. Yogyakarta.

Sutisna Sobar, Sora Lokita dan Sumaryo, 2010. Boundary Making Theory dan Pengelolaan Perbatasan di Indonesia : Dalam Mengelola Perbatasan Indonesia Didunia Tanpa Batas, Isu, Permasalahan dan Pilihan Kebijakan. Graha Ilmu. Yogyakarta.

Tarigan, Robinson. 2005. Ekonomi Regional, Teori dan Aplikasi. Penerbit : PT. Bumi Aksara. Cetakan Pertama. Jakarta.

Undang-Undang RI Nomor 43 Tahun 2008. Wilayah Negara. Graha Ilmu. Yogyakarta 
62 | Jurnal Bina Praja| Volume 5 Nomor 1 Edisi Maret 2013: 53 - 62 